\title{
New records of deep-water teleost fishes in the Balearic Sea and Ionian Sea (Mediterranean Sea)*
}

\author{
GIANFRANCO D’ONGHIA ${ }^{1}$, DOMINGO LLORIS², CHRISSI-YIANNA POLITOU ${ }^{3}$, \\ LETIZIA SION $^{1}$ and JOHN DOKOS ${ }^{3}$ \\ ${ }^{1}$ Dipartimento di Zoologia, Università degli Studi, Via E. Orabona 4, 70125 Bari, Italy. \\ E-mail: g.donghia@biologia.uniba.it \\ ${ }^{2}$ Institut de Ciències del Mar (CSIC), Passeig Marítim de la Barceloneta 37-49, 08039 Barcelona, Spain. \\ ${ }^{3}$ Institute of Marine Biological Resources, Hellenic Centre for Marine Research, Agios Kosmas, 16604 Helliniko, Greece.
}

\begin{abstract}
SUMMARY: During an EC-funded research carried out in the Mediterranean Sea deep-water fish (600-4000 m) were collected in the Balearic Sea as well as the western and eastern Ionian Sea. Caelorhynchus mediterraneus is a new record for the Balearic Sea, Cyclothone braueri, Hygophum benoiti, Paralepis speciosa, Chalinura mediterranea, Coryphaenoides guentheri, C. mediterraneus, Lepidion lepidion and Cataetyx laticeps for the western Ionian Sea, and Polyacanthonotus rissoanus, $C$. guentheri, C. mediterraneus, L. lepidion and C. laticeps for the eastern Ionian Sea. The bathymetric distribution of other species has been updated. Species richness decreased with depth in the three surveyed areas, showing a significant shift below $1500 \mathrm{~m}$. At depths greater than $1000 \mathrm{~m}$ macrourid and morid species were dominant except in the Balearic Sea, where Alepocephalus rostratus was found to be very abundant as deep as $1500 \mathrm{~m}$. At depths greater than $1500 \mathrm{~m}$ the dominant species were Bathypterois mediterraneus, $C$. mediterranea and $C$. guentheri. The results of this research confirm the scarcity of deep fish fauna in the Mediterranean compared to the Atlantic. For the greatest depths are concerned, the faunistic difference between the western and eastern Mediterranean seems to be most probably due to a lesser number of investigations on the eastern side rather than any real paucity of ichthyofauna.
\end{abstract}

Key words: new records, bathymetric distribution, geographic distribution, teleost, fish, Mediterranean Sea.

RESUMEN: NUEVAS CITAS DE PECES TELEÓSTeOS DE AGUAS PROFUNDAS EN LOS MARES BALEAR y IÓNICO (MAR MEDITERRÁNEO). - Se recolectaron especies de peces en el mar Balear y en el Iónico oriental y occidental, gracias a una investigación subvencionada por la CE en aguas profundas del Mediterráneo (600-4000 m). Caelorhynchus mediterraneus es una nueva cita para el mar Balear, Cyclothone braueri, Hygophum benoiti, Paralepis speciosa, Chalinura mediterranea, Coryphaenoides guentheri, C. mediterraneus, Lepidion lepidion y Cataetyx laticeps lo son para el mar Iónico occidental, Polyacanthonotus rissoanus, $C$. guentheri, C. mediterraneus, L. lepidion y C. laticeps para el mar Iónico oriental. También se ha puesto al día la distribución batimétrica de otras especies. En las tres áreas muestreadas se ha observado que la riqueza específica desciende con la profundidad, marcándose un cambio significativo por debajo de los $1500 \mathrm{~m}$. A profundidades superiores a $1000 \mathrm{~m}$ las especies de macrúridos y móridos fueron dominantes excepto para el mar Balear donde Alepocephalus rostratus fue la especie más abundante hasta $1500 \mathrm{~m}$. A profundidades superiores a los $1500 \mathrm{~m}$ las especies dominantes fueron Bathypterois mediterraneus, C. mediterranea y C. guentheri. Los resultados confirman la escasez de ictiofauna profunda en el Mediterráneo comparada con la del Atlántico. Hasta las máximas profundidades muestradas, la diferencia faunística entre el Mediterráneo occidental y oriental parece ser debida, más al menor número de investigaciones llevados a cabo en el Mediterráneo oriental, que no a unas determinadas pautas en la distribución y abundancia dicha ictiofauna.

Palabras clave: nuevas citas, distribución batimétrica, distribución geográfica, teleósteos, peces, Mediterráneo. 


\section{INTRODUCTION}

The first proof of the presence of a deep-sea fauna in the Mediterranean was found by the Washington exploration (1881-83), during which trawls were carried out in the western basin as deep as $3115 \mathrm{~m}$ and some macrourid fish were caught and described (Giglioli, 1881). After this exploration, knowledge of Mediterranean deep-sea fauna was mainly provided by the Hirondelle and Princesse Alice expeditions (1888-1922), the ichthyological results of which are reported in Zugmayer (1911) and Roule (1919). The most extensive deep-sea faunistic exploration in the Levant basin of the Mediterranean occurred during the voyages of the Pola (1890-1893). The Danish oceanographic cruises of the Thor (1908) and Dana (1928-29) also extended investigation from the Atlantic to the whole Mediterranean, even catching deep-sea fish at depths greater than $1000 \mathrm{~m}$ (Taning, 1918). All these cruises increased the knowledge of fish taxonomy and biodiversity (Tortonese, 1960; Ryland, 2000).

After the Danish oceanographic expeditions, the first noteworthy sampling of deep-sea fish in the Mediterranean was during the Polymède campaign made with the N.O. Jean Charcot (Geistdoerfer and Rannou, 1972) in the western basin and the German Meteor expedition in the eastern basin (Klausewitz, 1989).

In the last thirty years a large number of studies on ichthyofauna have also been conducted in both the western and eastern Mediterranean (Fredj and Maurin, 1987; Quignard and Tomasini, 2000, and references therein). However, they regard mostly depths shallower than $800 \mathrm{~m}$, while knowledge on the ichthyofauna below this bathymetry remains rather scarce. Fredj and Maurin (1987) estimated that only 6 nektobenthic fish species have been strictly recorded at depths greater than $500 \mathrm{~m}$ and very little is known about their distribution in the Mediterranean as a whole. Quignard and Tomasini (2000) reported that the divergence in the faunal composition between the western and eastern basins seems to increase due to the migratory flux of Lessepsian fish limited to east of the SiculoTunisian sill. This sill has long been considered a geographical barrier to the bathybenthic and bathypelagic faunal mixing between the west and east of the Mediterranean (Tortonese, 1964), raising the question of the poorness of the eastern basin.

In the context of the studies conducted at depths greater than $800 \mathrm{~m}$, both in the western
Mediterranean (e.g. Carpine, 1970; Geistdoerfer and Rannou, 1972; Rannou, 1975, 1976; Allué et al., 1984; Macpherson and Duarte, 1991; Stefanescu et al., 1992a, 1992b, 1993, 1994; Massutí et al., 1995; Sardà et al., 1998; Carrassón and Matallanas, 2001) and in the eastern Mediterranean (e.g. Golani, 198687; Klausewitz, 1989; Albertelli et al., 1992; Galil and Goren, 1994; Goren and Galil, 1997; Kallianiotis et al., 2000; Ungaro et al., 2001), only some of them extended the exploration below 1500 $\mathrm{m}$. Thus, little is known about both the vertical and geographic distribution of many species.

Photographs taken with automatic baited cameras dropped in the deep-water of the eastern Mediterranean have provided interesting contributions on active large scavengers dwelling on the deep-sea floor (Isaacs and Schwartzlose, 1975; Gilat and Gelman, 1984; Priede and Bagley, 2000; Jones et al., 2003). However, the baited camera approach suffers from the fact that quantification and even identification can be doubtful.

Considering the vast area covered by the Mediterranean below $1500 \mathrm{~m}$ and the various limitations occurring in the sampling of bathyal and abyssal fish species (Merrett and Haedrich, 1997), there is an evident need for further investigations in order to improve our knowledge of the fauna and zoogeography. An opportunity was recently provided by the DESEAS survey (finnanced by the EC), which explored Mediterranean bottoms down to $4000 \mathrm{~m}$ in depth. The main objective of this paper is to report the new records and to update the bathymetric distribution of the deep-water teleost fish collected during this survey. Due to the difficulties involved in deep-sea exploration (i.e. the time required to explore unknown deep-sea bottoms suitable to be trawled, the time required for a single haul and the decreasing sampling efficacy with depth), the results are qualitative.

\section{MATERIALS AND METHODS}

A deep-sea cruise was carried out in June 2001 in the Balearic Sea $\left(38^{\circ} 04^{\prime} 06^{\prime \prime} \mathrm{N} 1^{\circ} 44^{\prime} 18^{\prime \prime} \mathrm{E}\right.$ to $\left.40^{\circ} 48^{\prime} 18^{\prime \prime} \mathrm{N} 5^{\circ} 34^{\prime} 36^{\prime \prime} \mathrm{E}\right)$, the western Ionian Sea $\left(35^{\circ} 41^{\prime} 04^{\prime \prime} \mathrm{N} \quad 16^{\circ} 24^{\prime} 48^{\prime \prime} \mathrm{E}\right.$ to $38^{\circ} 18^{\prime} 30^{\prime \prime} \mathrm{N}$ $\left.17^{\circ} 47^{\prime} 00^{\prime \prime} \mathrm{E}\right)$, and the eastern Ionian Sea (36 $16^{\prime} 31^{\prime \prime} \mathrm{N}$ $21^{\circ} 54^{\prime} 23^{\prime \prime} \mathrm{E}$ to $36^{\circ} 51^{\prime} 24^{\prime}$ 'N $22^{\circ} 14^{\prime}$ '54'E) (Fig. 1).

The sampling was conducted with the otter trawl Maireta System (OTMS) using the R/V García del Cid (38 m long; 1500 HP). The OTMS (height 1.8- 


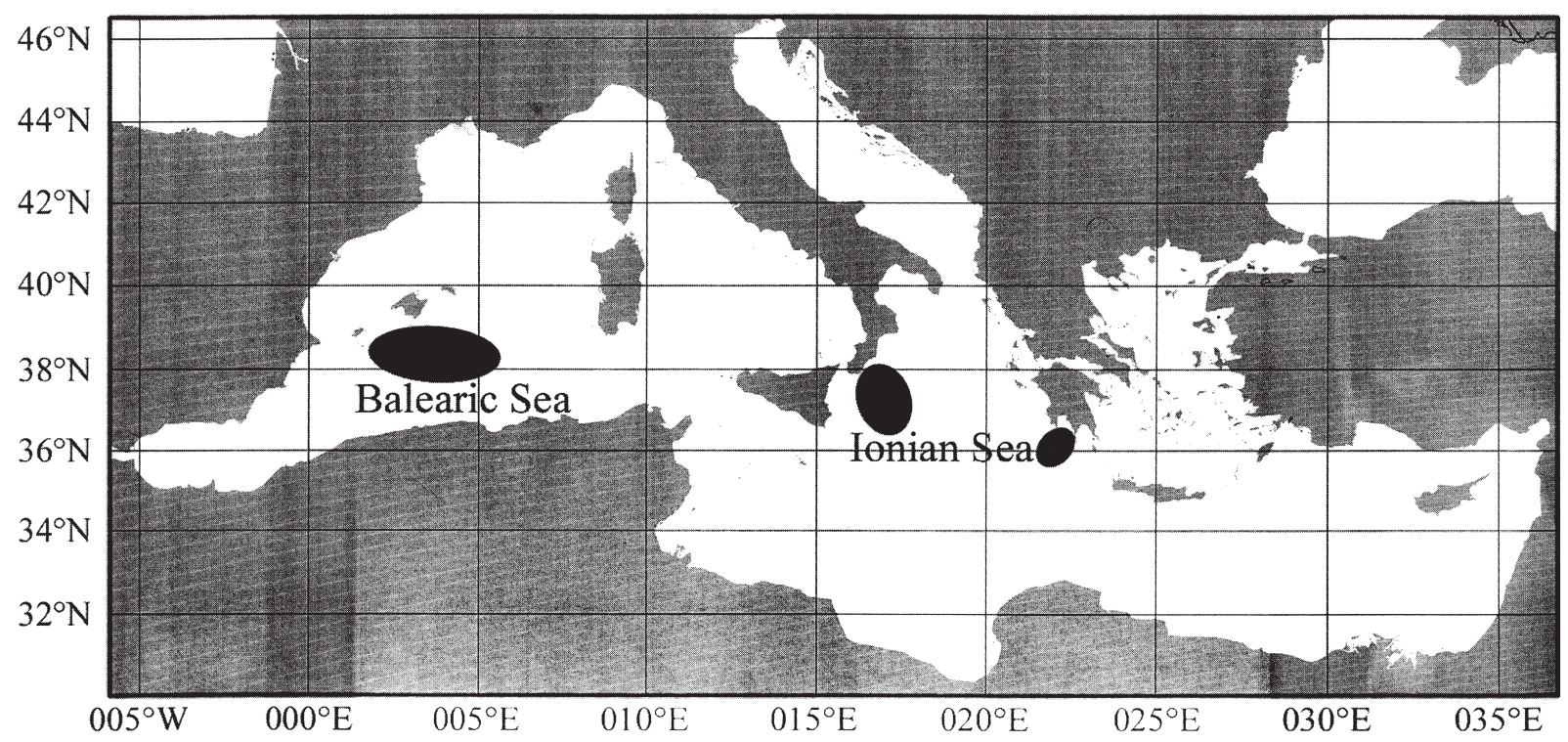

FIG. 1. - Map of the Mediterranean Sea with indication of the study areas during the DESEAS survey.

$2 \mathrm{~m}$; horizontal opening $14 \mathrm{~m}$ ) was trawled by a single warp and operated with a pair of rectangular iron otter boards $(1.20 \times 2.0 \mathrm{~m} ; 450 \mathrm{~kg})$ (Sardà et al., 1998). The duration of the tow was measured by means of the SCANMAR sonar system. The vessel speed and position were measured using differential GPS. The trawling was carried out during daylight hours. The number of hauls and their depth is reported in Table 1. The deepest haul considered in the Balearic Sea was carried out eastwards between $38^{\circ} 04^{\prime} \mathrm{N}-5^{\circ} 27^{\prime} \mathrm{E}$ and $38^{\circ} 05^{\prime} \mathrm{N}-5^{\circ} 34^{\prime} \mathrm{E}$. Haul duration ranged from 1 to 3 hours, but was standardised to $60 \mathrm{~min}$.

TABLE 1. - Number of hauls by depth carried out in the three study areas during the DESEAS survey.

\begin{tabular}{lccc}
\hline $\begin{array}{l}\text { Depth } \\
(\mathrm{m})\end{array}$ & Balearic area & $\begin{array}{c}\text { Western } \\
\text { Ionian area }\end{array}$ & $\begin{array}{c}\text { Eastern } \\
\text { Ionian area }\end{array}$ \\
\hline 600 & 1 & 1 & 2 \\
650 & 1 & 1 & 2 \\
800 & 1 & 1 & \\
802 & 1 & 1 & 1 \\
1000 & 1 & 2 & 1 \\
100 & 1 & 1 & 1 \\
1300 & 1 & 1 & \\
1500 & & & \\
1700 & 1 & 1 & 9 \\
22000 & & 1 & \\
2500 & & 10 & \\
2600 & 7 & & \\
2800 & & & \\
4300 & & & \\
Total hauls & & & \\
\hline
\end{tabular}

Specimens were identified on board following the nomenclature reported in Whitehead et al. (1984, 1986a, 1986b). Total (TL, mm) and pre-anal lengths (PAL, mm) were measured according to the species. Due to the explorative objective of the DESEAS survey and the qualitative nature of this paper, no abundance or biomass indices were computed. The depth range and the number of hauls where the species were found are reported together with the total number of specimens caught and their total biomass. The percentages in number and weight of the species collected in each area were computed excluding the pelagic fish, because they may have been captured during the hauling of the net. Only Lampanyctus crocodilus was included in the analysis since the adult specimens of this species live close to the bottom (Stefanescu and Cartes, 1992). Qualitative species similarity between the three areas was calculated by means of the Sssrensen (1948) index. The relationship between species richness and depth was analysed by regression function. The latter two analyses were also computed excluding the pelagic species.

\section{RESULTS}

\section{Ichthyofauna composition}

A total of 47 teleost fish belonging to 26 families were collected during the DESEAS survey and are listed in Table 2. Most of them are strictly benthic, 


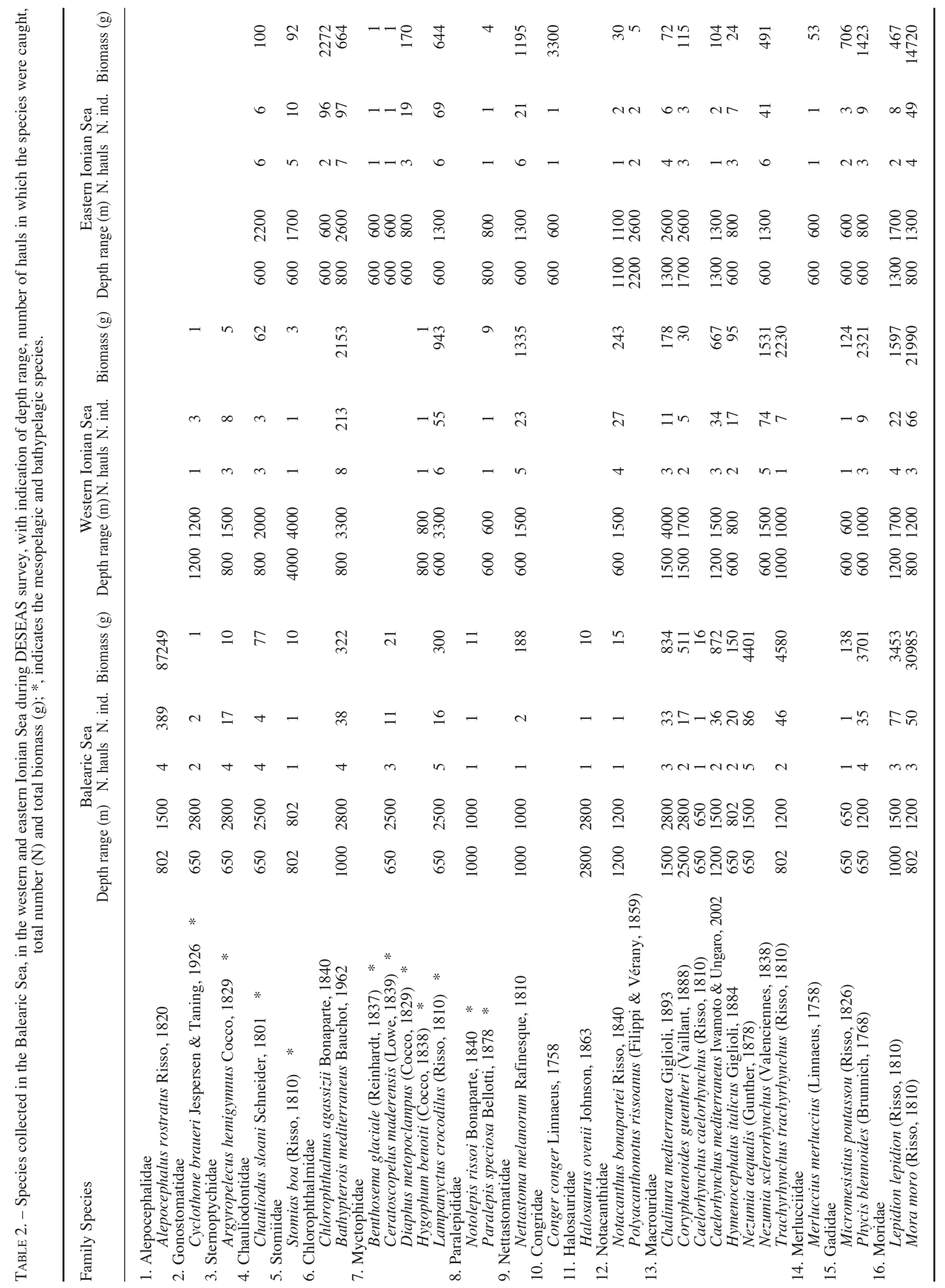

174 G. D'ONGHIA et al. 


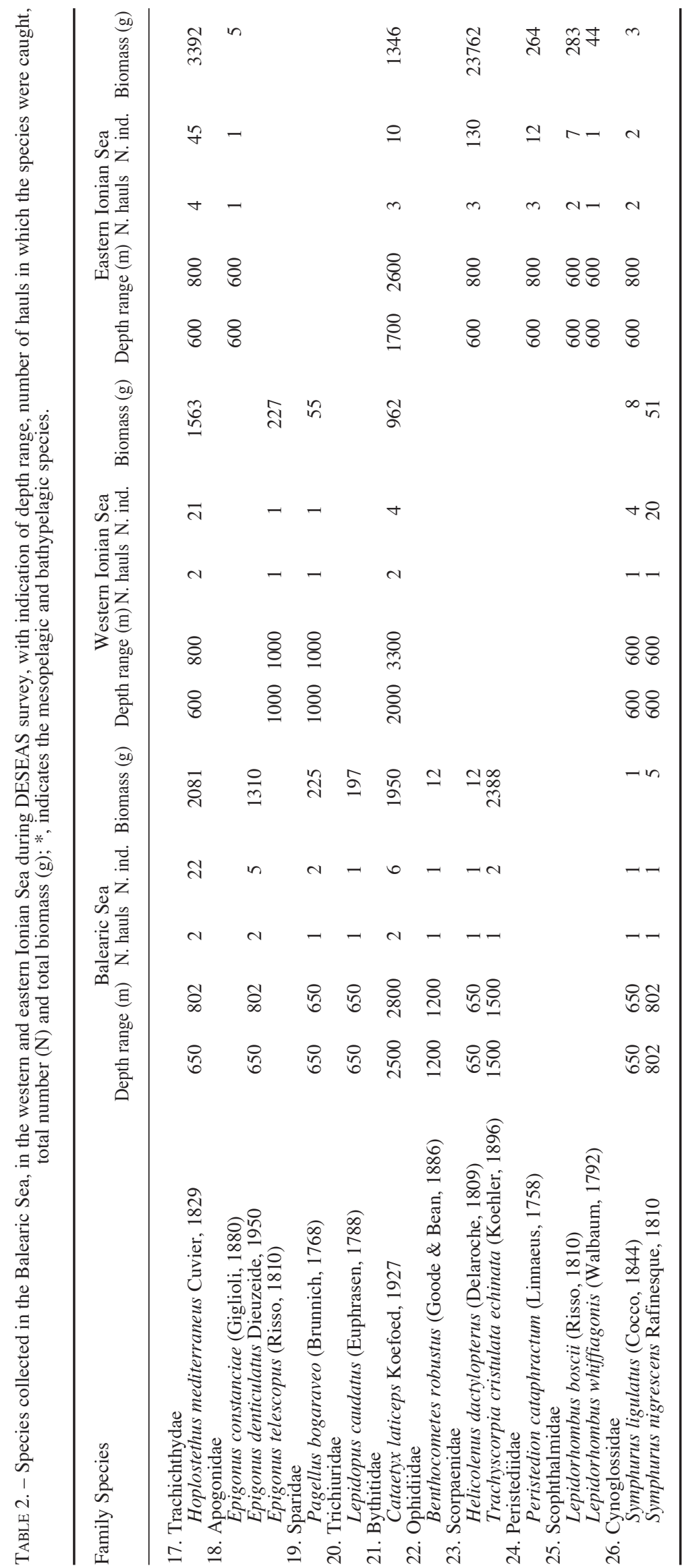

benthopelagic, bathybenthic and with demersal habits, while 11 species are mesopelagic and bathypelagic. Excluding these latter species (with the exception of L. crocodilus), 27, 20 and 25 species were captured in the Balearic Sea, the western and eastern Ionian Sea respectively.

In the Balearic Sea, Alepocephalus rostratus constituted about $42 \%$ in number and $60 \%$ in weight of the specimens collected. Lepidion lepidion and Mora moro accounted for $8.3 \%$ of the total number and $21 \%$ of total biomass respectively. The family Macrouridae was represented by the highest number of species (7), about $26 \%$ of the total number and $7.8 \%$ of the total biomass of the specimens collected. The greatest abundance and biomass were provided by the grenadiers Nezumia aequalis $(9.3 \%)$ and Trachyrhynchus trachyrhynchus (3.1\%) respectively. Apart from Bathypterois mediterraneus, Phycis blennoides and Hoplostethus mediterraneus, the remaining species were represented in small numbers and biomass.

In the western Ionian Sea, B. mediterraneus was the most abundant species in number $(33.7 \%$ of the specimens captured) while M. moro constituted $57.3 \%$ of the biomass of all specimens collected. A noteworthy contribution to the fish fauna of this area was provided by the Macrouridae family as a whole $(23.6 \%$ in number and $12.3 \%$ in weight), of which $N$. sclerorhynchus and T. trachyrhynchus showed the highest percentage of abundance $(11.7 \%)$ and biomass $(5.8 \%)$ respectively. Apart from L. crocodilus, Nettastoma melanorum, Notacanthus bonapartei, L. lepidion and H. mediterraneus, the other species were present in very small numbers.

In the eastern Ionian Sea, Helicolenus dactylopterus constituted $19.6 \%$ in number and $42.6 \%$ in weight of the specimens captured in the area. Chlorophthalmus agassizii and $B$. mediterraneus each accounted for $14.5 \%$ in number and $M$. moro for $26.4 \%$ in weight. The Macrouridae family represented $9 \%$ in number but only $1.5 \%$ in weight. $N$. scle- 


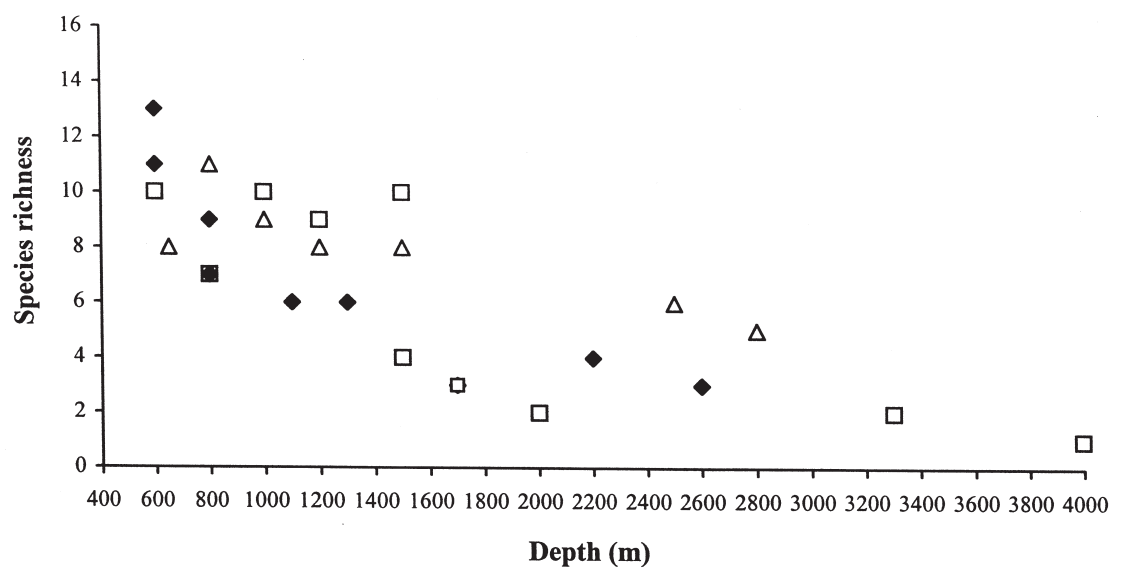

FIG. 2. - Relationship between species richness and depth during the DESEAS survey $(\Delta$, Balearic Sea; $\square$, Western; and $\bullet$, Eastern Ionian Sea).

rorhynchus was the main component $(6.3 \%$ in number). Noteworthy abundance and biomass percentages were found for $L$. crocodilus and $H$. mediterraneus respectively.

The Sșrensen similarity indexes were $77 \%$ between the Balearic and western Ionian, 71\% between the western and eastern Ionian, and 62\% between the Balearic and eastern Ionian.

In all three study areas the species richness decreased with depth, showing a shift below $1500 \mathrm{~m}$ (Fig. 2). The relationship was best described by a power function (species richness $=4991.3$ depth $\left.{ }^{-0.9425}\right)$ with statistically significant results $\left(r^{2}=\right.$ $0.66 ; \mathrm{p}<0.01)$.

\section{New records}

\section{Polyacanthonotus rissoanus}

(Filippi and Vérany, 1859)

This benthopelagic species had been collected between the Balearic Islands and Sardinian waters at a depth of $2830 \mathrm{~m}$ (Geistdoerfer and Rannou,1972). Recently, it was caught by Stefanescu et al. (1992a) and Moranta et al. (1998) in the Catalan Sea and off the Balearic Islands respectively. In the eastern Mediterranean a specimen was found at a depth of $1400 \mathrm{~m}$ (171 mm TL) (Goren and Galil, 1997). During the DESEAS cruise 2 specimens (150 and $180 \mathrm{~mm}$ TL) were captured for the first time in the eastern Ionian Sea from depths of 2200 and $2600 \mathrm{~m}$.

\section{Chalinura mediterranea Giglioli, 1893}

The first finding of this species in the Mediterranean was in the Tyrrhenian Sea from depths of 2805-2904 m (Giglioli, 1881). Specimens were collected off Nice at depths of 2200-2400 m (Carpine, 1970). Geistdoerfer and Rannou (1972) captured 14 specimens at four stations off North Africa between the Balearic Islands and Sardinia, from 2370 to 2830 $\mathrm{m}$. In the Catalan Sea C. mediterranea was found between 1308 and $2251 \mathrm{~m}$ (Stefanescu et al., 1992a) and south of the Balearic Islands between 1400 and $1800 \mathrm{~m}$ (Moranta et al., 1998). In this sector, during the present study 33 specimens (22-98 mm PAL) were sampled at 1500, 2500 and $2800 \mathrm{~m}$, updating the vertical distribution shown previously.

This is the first record of the species from the western Ionian Sea, 11 specimens (8-85 mm PAL) were collected between 1500 and $4000 \mathrm{~m}$, the deepest the species has been sampled by trawling in the Mediterranean.

In the eastern Ionian Sea $\left(35^{\circ} 54^{\prime} \mathrm{N} 22^{\circ} 21^{\prime} \mathrm{E}\right) C$. mediterranea was captured at $4500 \mathrm{~m}$ using traps (Albertelli et al., 1992), a depth record for the Mediterranean. Records of $C$. mediterranea in the eastern Mediterranean were taken using lander platforms equipped with baited cameras and baited trap deployments between 1500 and $4264 \mathrm{~m}$ (Jones in Priede and Bagley, 2000; Jones et al., 2003). During the DESEAS sampling in the eastern Ionian Sea 6 specimens (30-65 mm PAL) were collected between 1300 and $2600 \mathrm{~m}$.

Coryphaenoides guentheri (Vaillant, 1888)

C. guentheri is widespread throughout the Mediterranean (Whitehead et al., 1986a). This species was found for the first time in the western Mediterranean between Balearic and Sardinian waters (2370-2830 m) (Geistdoerfer and Rannou, 1972 as Chalinura guentheri). In the Catalan Sea, it is known at depths between 1200 and $2251 \mathrm{~m}$ 
(Stefanescu et al., 1992a, 1994), and off the southern Balearic Islands between 1400 and $1800 \mathrm{~m}$ (Moranta et al., 1998). In the present study $17 \mathrm{spec}-$ imens (35-82 mm PAL) were hauled at 2500 and $2800 \mathrm{~m}$ in the Balearic Sea; 5 specimens $(24-60 \mathrm{~mm}$ PAL, $1500-1700 \mathrm{~m})$ and 3 specimens $(55-88 \mathrm{~mm}$, $1700-2600 \mathrm{~m})$ were collected in the western and eastern Ionian Sea respectively.

\section{Caelorhynchus mediterraneus Iwamoto} and Ungaro, 2002

This grenadier fish has been recently described by Iwamoto and Ungaro (2002) from specimens collected in the western and central Mediterranean. These authors reported that the species was previously recorded in the western Mediterranean as $C$. vaillanti off Corsica (Raimbault, 1963) and in the Ligurian Sea (Orsi and Relini, 1972), as C. occa in the Catalan Sea by Allué (1983) and Allué et al. (1984) and as C. labiatus in the Catalan Sea by Stefanescu et al. (1992a, 1992b) and Massutí et al. (1995). In the Adriatic Sea the species was found at depths between 1015 and $1196 \mathrm{~m}$, initially reported as C. occa (Ungaro et al., 2001) and then described as a new species (Iwamoto and Ungaro, 2002).

In the Catalan Sea the misidentified $C$. labiatus (actually C. mediterraneus) was found in the depth range of 1046-2201 m (Stefanescu et al., 1992a) and off the southern Balearic Islands between 1200 and $1800 \mathrm{~m}$ (Moranta et al., 1998). The first finding of C. labiatus in the eastern Mediterranean recorded by Galil and Goren (1994) from depths of 1390-1500 $\mathrm{m}$, not cited by Iwamoto and Ungaro (2002), most probably also corresponds to $C$. mediterraneus.

The specimens of $C$. mediterraneus collected during the DESEAS survey had the same features (snout shape, squamation, color and size) indicated in the description of the species (op. cit.). In the Balearic Sea 36 specimens (33-90 mm PAL) were found at depths of 1200 and $1500 \mathrm{~m}$. The findings in the western and eastern Ionian Sea represent the first records of the species in these two areas. In the former, 34 specimens (38-86 mm PAL) were sampled from depths of 1200$1500 \mathrm{~m}$, and in the latter only 2 specimens (95 and 107 $\mathrm{mm}$ PAL) were caught at a station at $1300 \mathrm{~m}$.

\section{Lepidion lepidion (Risso, 1810)}

The presence of Lepidion lepidion in the western Mediterranean (between north Africa and south Sardinia, at $2450 \mathrm{~m}$ depth) dates back to the
Polymède campaign (Geistdoerfer and Rannou, 1972). In the Catalan Sea this fish was found in the depth range of 984-2251 m (Stefanescu et al., 1992a) and off the southern Balearic Islands between 1000 and $1800 \mathrm{~m}$ (Moranta et al., 1998). In this latter area, during the present research, $77 \mathrm{spec}-$ imens (70-318 mm TL) were captured at depths between 1000 and $1500 \mathrm{~m}$.

L. lepidion has recently been recorded in the Adriatic Sea from depths of 1015-1196 m (Ungaro et al., 2001). In the eastern Mediterranean its occurrence has been recorded using deep-water photographic equipment and baited traps: in the Cretan Sea between 1500 and $2500 \mathrm{~m}$ and in the Rhodes Basin between 2300 and $3850 \mathrm{~m}$ (Jones in Priede and Bagley, 2000; Jones et al., 2003). During the DESEAS cruise L. lepidion was found down to 1700 $\mathrm{m}$ in both the western and eastern Ionian Sea, with 22 specimens (145-291 mm TL) in the former and 8 specimens (165-310 mm TL) in the latter.

\section{Cataetyx laticeps Koefoed, 1927}

One juvenile and two adults were sampled for the first time in the Mediterranean at depths of 2830 and 2370 m respectively during the Polymède campaign (Geistdoerfer and Rannou, 1972). C. laticeps was collected between 1739 and $2251 \mathrm{~m}$ in the Catalan Sea (Stefanescu et al., 1990, 1992a) and down to $1800 \mathrm{~m}$ south of the Balearic Islands (Moranta et al., 1998). In this area 6 specimens $(90-500 \mathrm{~mm} \mathrm{TL})$ were collected from depths of 2500 and $2800 \mathrm{~m}$ during the DESEAS cruise.

In the eastern Mediterranean one specimen (350 $\mathrm{mm}$ TL) was found at a depth of $1400 \mathrm{~m}$ off the Israeli coast (Goren and Galil, 2002). During this research 4 specimens (311-384 $\mathrm{mm}$ TL) were collected in the western Ionian between 2000 and 3300 $\mathrm{m}$ and 10 specimens (200-397 mm TL) in the eastern Ionian between 1700 and $2600 \mathrm{~m}$.

Among the pelagic species, Cyclothone braueri Jespersen and Taning, 1926, Hygophum benoiti (Cocco, 1838) and Paralepis speciosa Bellotti, 1878 are new records for the western Ionian Sea.

\section{Depth distribution records}

\section{Halosaurus ovenii Johnson, 1863}

This benthopelagic species was reported between 400 and 1700 m (Whitehead et al., 1986a). A speci- 
men (229 mm TL) was collected off the Balearic Islands $\left(38^{\circ} 04^{\prime} \mathrm{N} 5^{\circ} 27^{\prime} \mathrm{E}\right.$; $\left.38^{\circ} 05^{\prime} \mathrm{N} 5^{\circ} 34^{\prime} \mathrm{E}\right)$ at a depth of $2800 \mathrm{~m}$. The present finding represents the deepest record of the species in both the Mediterranean and the northeast Atlantic.

\section{Bathypterois mediterraneus Bauchot, 1962}

The tripodfish was previously collected by Geistdoerfer and Rannou (1972) between the Catalan Sea and off north Africa at depths between 2140 and $2830 \mathrm{~m}$. More recently, it was recorded both in the Catalan Sea as deep as $2251 \mathrm{~m}$ (Stefanescu et al., 1992a; Morales-Nin et al., 1996b) and off the southern Balearic Islands down to 1800 m (Moranta et al., 1998). In this latter area during the present study specimens were found between 1000 and $2800 \mathrm{~m}$.

The occurrence of $B$. mediterraneus in the western Ionian Sea has long been known (Bauchot, 1963; Geistdoerfer and Rannou, 1972). The present finding, between 800 and $3300 \mathrm{~m}$, broadens its known vertical distribution in the area and in the whole Mediterranean Sea. The presence of $B$. mediterraneus in the eastern Ionian Sea and slightly eastwards was reported by Klausewitz (1989) (1433-1626 m south-east of Crete and 2572-2596 m south-west of Cyprus). During the DESEAS cruise it was collected between 800 and $2600 \mathrm{~m}$.

\section{Lampanyctus crocodilus (Risso, 1810)}

Carpine (1970) sampled some specimens of this species off Nice trawling at depths between 2200 and $2400 \mathrm{~m}$. Moranta et al. (1998) reported the occurrence of the species south of the Balearic Islands at a maximum depth of $1800 \mathrm{~m}$. During the DESEAS cruise specimens were collected from 650 to $2500 \mathrm{~m}$.

L. crocodilus has been collected in the Ionian Sea since the Thor expedition in the Mediterranean (Taning, 1918). During June 2001, specimens were caught in the western Ionian from 600 down to 3300 $\mathrm{m}$, the greatest depth at which the species has been found in the area and anywhere in the Mediterranean. In the eastern Ionian it was found down to $1300 \mathrm{~m}$ in depth.

\section{Nettastoma melanorum Rafinesque, 1810}

The species was recorded off the Balearic Islands down to $1400 \mathrm{~m}$ by Moranta et al. (1998). During the DESEAS survey, it was captured between 600 and $1500 \mathrm{~m}$ in the western Ionian and between 600 and $1300 \mathrm{~m}$ in the eastern Ionian.

\section{Phycis blennoides (Brünnich, 1768)}

Although in the Catalan Sea Phycis blennoides was recorded in the depth range 960-1308 m (Stefanescu et al., 1992a), off the southern Balearic Islands it was only collected down to about $1000 \mathrm{~m}$ (Moranta et al., 1998). In this area during the DESEAS survey the species was sampled as deep as $1200 \mathrm{~m}$.

In the Levant basin P. blennoides was recorded down to $1200 \mathrm{~m}$ in depth (Goren and Galil, 1997). This teleost is common in the western Ionian Sea where it is generally caught at a maximum depth of 800 m (Parenzan, 1960; Pastore, 1976; Franceschini et al., 1993; Matarrese et al., 1996). In June 2001, for the first time, it was sampled down to $1000 \mathrm{~m}$.

\section{Mora moro (Risso, 1810)}

This teleost is one of the most abundant species between 800 and $1400 \mathrm{~m}$ off the southern Balearic Islands (Moranta et al., 1998). It has been caught off Crete from 800 to $1000 \mathrm{~m}$ (Kallianiotis et al., 2000) and in the Adriatic Sea from 826 to $1196 \mathrm{~m}$ (Ungaro et al., 2001). During the DESEAS campaign $M$. moro was sampled down to $1200 \mathrm{~m}$ in the western Ionian and $1300 \mathrm{~m}$ in the eastern Ionian.

Notacanthus bonapartei Risso, 1840 and Nezumia sclerorhynchus (Valenciennes, 1838) are common species in the Ionian Sea, generally caught at a maximum depth of $800 \mathrm{~m}$ (Parenzan, 1960; Papaconstantinou, 1988; Matarrese et al., 1996; D'Onghia et al., 1998a). During the present study both species were sampled between 600 and $1500 \mathrm{~m}$ on the western side of the Ionian Sea. $N$. bonapartei was collected at a depth of $1100 \mathrm{~m}$ and N. sclerorhynchus at a depth of $1300 \mathrm{~m}$ in the eastern area of this basin.

The species Trachyrhynchus trachyrhynchus (Risso, 1810), Epigonus telescopus (Risso, 1810) and Pagellus bogaraveo (Brünnich, 1768) have also been frequently recorded in the Ionian basin down to $800 \mathrm{~m}$ (Parenzan, 1960; Pastore, 1976; Franceschini et al., 1993; Matarrese et al., 1996). In June 2001 these fish were caught in the western area at a depth of $1000 \mathrm{~m}$.

Trachyscorpia cristulata echinata (Koehler, 1896) was found during a haul carried out at $1500 \mathrm{~m}$ 

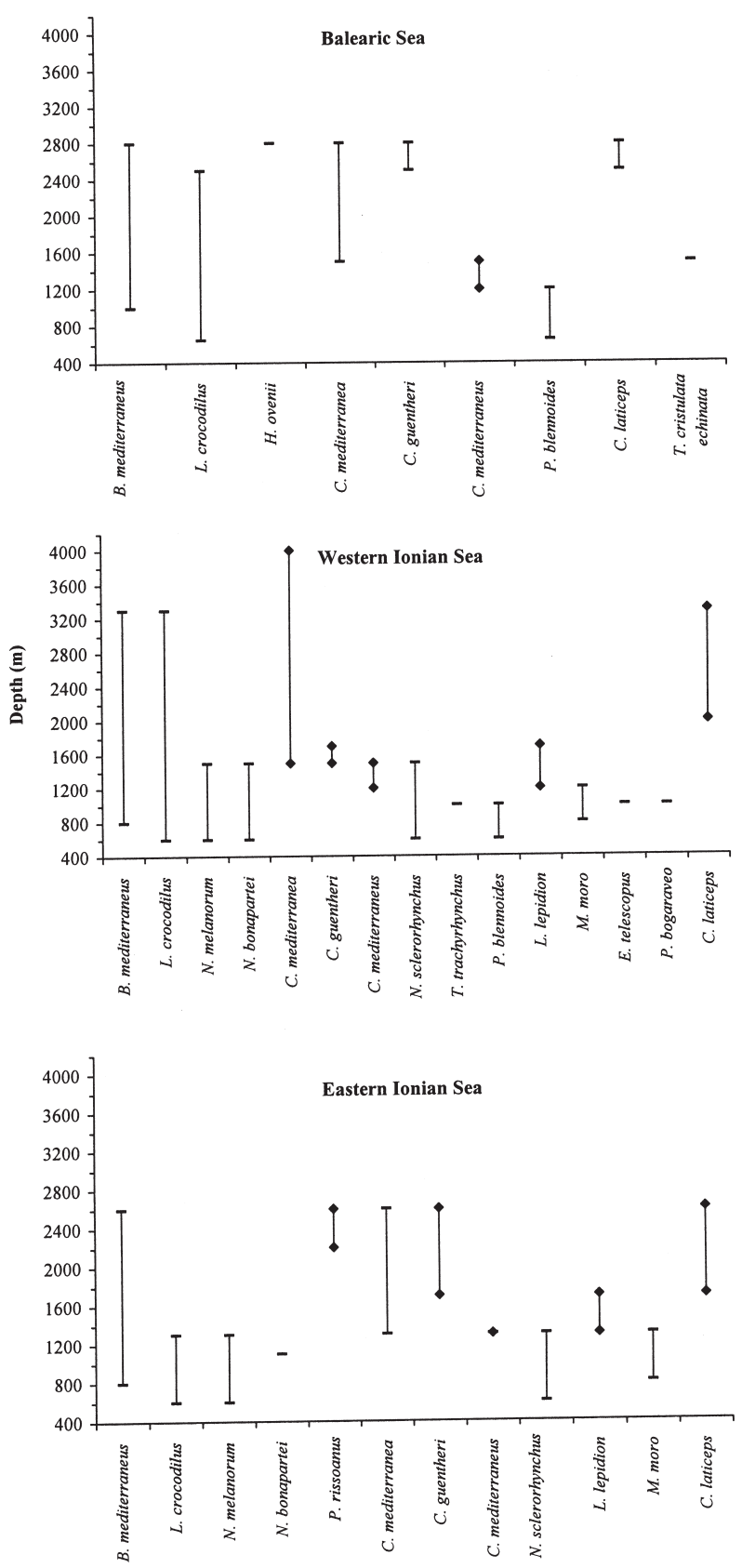

FIG. 3. - Updated depth ranges of the deep-water benthopelagic and demersal teleost fishes collected during the DESEAS survey. The symbol $(\bullet)$ indicates new records for the study areas.

in the Balearic Sea. Its previous finding was in the Alboran Sea (Maurin, 1962; Fredj and Maurin, 1987) and off the Balearic Islands (Massutí et al., 1993), but at a maximum depth of $1000 \mathrm{~m}$. Recently, a small specimen (144 mm TL) was collected off western Sicily at a depth of $600 \mathrm{~m}$ (Ragonese and Giusto, 1999).

The new records and the updated depth ranges of the benthopelagic and demersal species collected during the DESEAS survey are shown in Figure 3.

\section{DISCUSSION}

Despite sampling limitations, which caused a different number of hauls and a different sounded depth range in the three areas, this study provides new faunistic and biogeographic data on the Mediterranean deep-sea ichthyofauna.

New records of deep-water fish are presented mostly for the Ionian Sea, in which the least research into deep-sea fish fauna has been carried out.

The finding of $C$. mediterraneus in all three areas confirms its distribution throughout the Mediterranean (Iwamoto and Ungaro, 2002). The specimens described as C. labiatus in the Levant Sea (Galil and Goren, 1994) are probably $C$. mediterraneus.

The absence of $C$. caelorhynchus in our samples from the Ionian Sea was due to the small number of hauls within the species depth range (Cohen et al., 1990). The species is rather common on the upper slope in the Ionian Sea (D'Onghia et al., 1998a, 2000; Labropoulou and Papaconstantinou, 2000).

The depth distribution of several species has been updated. For L. crocodilus, B. mediterraneus and $C$. laticeps, it is the greatest depth recorded in the Mediterranean. In our opinion, the greatest depth at which some pelagic species were found cannot be reliably considered as the species depth range since they may have been captured in shallower waters during the hauling of the net. However, bathypelagic species, such as Stomias boa and Chauliodus sloanei, have also been reported below $3000 \mathrm{~m}$ in the Atlantic (Tortonese, 1960). Moreover, the presence of this latter bathypelagic fish, together with $B$. mediterraneus and $C$. laticeps, has been documented at a depth of $2900 \mathrm{~m}$ in the Levantine basin of the Mediterranean Sea using a remote operating vehicle (Galil, 2004).

Although some differences were shown in the ichthyofauna composition between the three areas, the same pattern of the species richness with depth was shown in each of them. Below a depth of $1000 \mathrm{~m}$, the species of the Macrouridae and Moridae families were dominant in all three areas investigated, with the exception of the overwhelming presence of A. rostratus in the Balearic Sea. At depths greater than $1500 \mathrm{~m}$, the dominant species were $B$. mediterraneus, $C$. mediterranea and $C$. guentheri (Stefanescu et al., 1992a, 1993; Moranta et al., 1998; Goren and Galil, 2002). In agreement with the observations of the latter authors, L. crocodilus was found with noteworthy abundance on both sides of the Ionian Sea. 
Despite the sampling limitations, the qualitative faunistic similarity between the three areas was rather high. Considering that some common species, such as $C$. agassizii, C. caelorhynchus and L. boscii, were only found in one of the areas sampled, the similarity between the areas can be considered even higher than that estimated. In addition, this survey suffers from limitations common to many simple exploratory tools, such as the fact that its samples are highly selective. Thus, species known to be distributed in both the Balearic Sea and the Ionian Sea were not caught by the net used.

The number and biomass shown for A. rostratus in the western Mediterranean according to previous studies (Stefanescu et al., 1993; Morales-Nin et al., 1996a; Moranta et al., 1998), and the total lack in the two easternmost areas in the ten hauls carried out in its depth distribution range (984-2209 m, according to Stefanescu et al., 1992a), might be the consequence of its exclusive distribution in the western Mediterranean. The same consideration may also be valid for $N$. aequalis, which seems to be only distributed on this side of the Mediterranean, although the main check-lists report this species distributed throughout the basin (Whitehead et al., 1986a; Bauchot, 1987; Cohen et al., 1990). On the other hand, the presence of $N$. sclerorhynchus in the western Mediterranean has long been known (e.g. Rannou, 1975, 1976).

The absence of these species in the eastern Mediterranean remains an open question. According to Galil and Goren (1994), their absence might be due to the distance from the point of faunal entry at the Gibraltar Strait and to the shallow SiculoTunisian sill. However, this contrasts with the fact that many other deep-water Atlantic species are widespread in the Mediterranean. Moreover, the exclusive abundant occurrence of A. rostratus and $N$. aequalis only off the Balearic Islands might also be the consequence of the different trophic conditions between the west and east Mediterranean. In fact, megafaunal biomass in the deep sea is linked to the surface productivity regime (Haedrich and Rowe, 1977; Gordon 1979; Merrett, 1987). As recently reported by Danovaro et al. (1999), primary production, chlorophyll $a$ concentrations and carbon fluxes in the western Mediterranean are significantly higher than in the eastern Mediterranean, and influence bacterial and meiofaunal densities and biomass. Melley et al. (2000) reported that, in the context of oligotrophic Mediterranean conditions, the western basin shows nitrogen and phosphate concentrations of about 90 and $129 \%$ respectively greater than the Ionian Sea. Maynou and Cartes (2000) reported that phytoplankton pigment concentration differs by almost an order of magnitude between the western and eastern Mediterranean Sea.

In addition, Moranta et al. (1998) reported that $A$. rostratus is more abundant south of the Balearic Islands (Balearic Sea in this study) than north of the islands where the species L. lepidion and B. mediterraneus are more abundant. According to Moranta et al. (1998) and Massutí et al. (2004), the differences between the megafauna of these areas could be due to the differences in trophic transfer systems. South of the Balearic Islands where much of the food is of planktonic origin, the most abundant species is $A$. rostratus, which feeds mainly on gelatinous macroplankton (Carrassón and Matallanas, 1990), while north of the Balearic Islands, where benthic and benthopelagic organisms form the important food resources (Cartes et al., 1994), the most abundant species are L. lepidion and B. mediterraneus, which prey on benthic decapods (Carrassón et al., 1997) and benthopelagic crustaceans (Carrassón and Matallanas, 2001) respectively. These different conditions in the trophic web, due to surface productivity and the presence of canyons, could explain the absence of A. rostratus in the Ionian Sea, where submarine canyons are widespread on the slope (D’Onghia et al., 1998b).

Even though these conditions could be the cause of the exclusive presence of $A$. rostratus in the western Mediterranean, they do not explain the lack of $N$. aequalis in the eastern basin. In fact, this fish has a feeding niche that overlaps with $N$. sclerorhynchus and C. caelorhynchus (Geistdoerfer, 1975; Macpherson, 1979; Marques and Almeida, 1998), which are both abundant in the eastern Mediterranean. The diet overlap could be responsible for the competitive exclusion of $N$. aequalis in the Ionian Sea, since N. sclerorhynchus is the dominant macrourid fish in this basin at the same depths at which $N$. aequalis is distributed in the Balearic Sea (Moranta et al., 1998; and in this study). N. aequalis may be present in the western and eastern Ionian Sea but since it is less abundant than N. sclerorhynchus it could have been misidentified because its identification depends on analysis of scales, otoliths and morphological features (Cohen et al., 1990; Marques and Almeida, 1998).

The DESEAS results confirm the abundance of C. agassizii and H. dactylopterus on the upper slope of the eastern Ionian Sea. This might be due to the 
absence of fishing pressure in this area below 400$500 \mathrm{~m}$ in depth (D'Onghia et al., 2003). However, according to these authors, the differences in the ichthyofauna composition and abundance between the eastern and western Ionian upper slope could also be due to the different hydrographic conditions on the two sides of the basin. Along the Greek coasts the water masses are warmer and have high salinity, while along the Italian ones they are colder and slightly less saline (Robinson and Golnaraghi, 1992; Theocaris et al., 1993).

Finally, the DESEAS results confirm the scarcity of deep fish fauna in the Mediterranean compared to the Atlantic (Haedrich et al., 1980; Gordon and Duncan, 1985; Haedrich and Merrett, 1988). The recent origin of the deep-sea fauna in the Mediterranean, the "canal effect", the high temperature and the oligotrophy of the basin are considered the main causes of this qualitative and quantitative poverty (Fredj and Maurin, 1987; Bouchet and Taviani, 1992; Quignard and Tomasini, 2000).

Although some differences have been detected between the ichthyofauna of the three study areas, common patterns are shown in the faunistic composition at the greatest depths, indicating that the difference between the western and eastern Mediterranean seems to be most probably due to a lesser amount of research work on the eastern side rather than a real paucity of ichthyofauna. For instance, Tortonese (1960) reported in his remarks on the Mediterranean deep-sea fishes that " $L$. crocodilus becomes gradually scarcer eastward". On the contrary, during the DESEAS cruise this fish was found to be more abundant in the eastern Ionian Sea than in the Balearic Sea. L. crocodilus is also one of the most abundant deep-sea fishes of the Levantine basin (Goren and Galil, 2002).

Considering the different swimming behaviour of the deep-water fishes and the sampling limitations of the trawl net, this study confirms that gaps in the knowledge on the deep-sea fauna and zoogeography of the Mediterranean can only be overcome by using different recording techniques and sampling methods.

\section{ACKNOWLEDGEMENTS}

This work was supported by the Directorate General of Fisheries of the European Commission as part of the project DESEAS (Exploratory survey to collect data of the exploited and virgin stocks of deep-sea shrimp A. antennatus, of interest to the CFP - Study contract $n^{\circ}$ 2000/39, DGXIV). The authors wish to thank V. Catalano for providing helpful literature.

\section{REFERENCES}

Albertelli, G., P.M. Arnaud, N. Della Croce, N. Drago and A. Eleftheriou. - 1992. The deep Mediterranean macrofauna caught by traps and its trophic significance. C.R. Acad. Sci. Paris, t. 315, Série III: 139-144.

Allué, C., J.A. Rucabado, D. Lloris and R. Allué. - 1984. Contribucion al conocimiento de la ictiofauna abisal del Mediterráneo español. Bull. Soc. Catal. Ictiol. Herpetol., 10: 8-13.

Allué, R. - 1983. Coelorhynchus occa (Goode and Bean, 1806) (Osteichthyes, Macrouridae), primera cita en el Mediterráneo español. Bull. Soc. Catal. Ictiol. Herpetol., 5: 2-5.

Bauchot, M.-L. - 1963. Description d'un nouveau Bathypterois mediterranéen. Vie Milieu, 13(4): 613-647.

Bauchot, M.-L. - 1987. Poissons osseux. In: W. Fisher, M.-L. Bauchot and M. Schneider (éds.). Fiches FAO d'Identification des Espèces pour les Besoins de la Pêche. (Révision 1). Méditerranée et Mer Noire. Zone de Pêche 37. Vol. II. Vertébrés. FAO, Roma: 891-1422.

Bouchet, P. and M. Taviani. - 1992. The Mediterranean deep-sea fauna: pseudopopulations of Atlantic species?. Deep-Sea Res., 39(2): 169-184.

Carpine, C. - 1970. Une expérience de chalutage profond. Bull. Inst. Océanogr. Monaco, 69(1408): 1-16.

Carrassón, M. and J. Matallanas. - 1990. Preliminary data about the feeding habits of some deep-sea Mediterranean fishes. J. Fish Biol., 36: 461-463.

Carrassón, M. and J. Matallanas. - 2001. Feeding ecology of the Mediterranean spiderfish, Bathypterois mediterraneus (Pisces: Chlorophthalmidae), on the western Mediterranean slope. Fish. Bull., 99: 266-274.

Carrassón, M., J. Matallanas and M. Casadevall. - 1997. Feeding strategies of deep-water morids on the western Mediterranean slope. Deep-Sea Res., 44(9,10): 1685-1699.

Cartes, J.E., J.B. Company and F. Maynou. - 1994. Deep-water decapod crustacean communities in the Northwestern Mediterranean: influence of submarine canyons and season. Mar. Biol., 120: 221-229.

Cohen, D.M., T. Inada, T. Iwamoto and N. Scialabba. - 1990. FAO species catalogue. Vol. 10. Gadiform fishes of the world. FAO Fish. Synop., 125 pp.

Danovaro, R., A. Dinet, G. Duineveld and A. Tselepides. - 1999. Benthic response to particulate fluxes in different trophic environments: a comparison between the Gulf of Lions-Catalan Sea (western Mediterranean) and the Cretan Sea (eastern Mediterranean). Prog. Oceanogr., 44: 287-312.

D’Onghia, G., M. Basanisi and A. Tursi. - 2000. Population structure, age and growth of macrourid fish from the upper slope of the Eastern-Central Mediterranean. J. Fish Biol., 56(5): 12171238.

D’Onghia, G., F. Mastrototaro, A. Matarrese, C.-Y. Politou and Ch. Mytilineou. - 2003. Biodiversity of the upper slope demersal community in the eastern Mediterranean: preliminary comparison between two areas with and without trawl fishing. $J$. Northw. Atl. Fish. Sci., 31: 263-273.

D’Onghia, G., A. Tursi, P. Maiorano, A. Matarrese and M. Panza. - 1998a. Demersal fish assemblages from the bathyal grounds of the Ionian Sea (Middle-Eastern Mediterranean). Ital. J. Zool., 65(Suppl.): 287-292.

D’Onghia, G., A. Tursi, P. Maiorano and M. Panza. - 1998 b. Caratterizzazione geografica dello stock di Aristeus antennatus (Risso, 1816) (Crustacea, Decapoda) nel Mar Ionio settentrionale. Biol. Mar. Medit., 5(2): 239-251.

Franceschini, G., F. Andaloro and G. Diviacco. - 1993. La macrofauna dei fondi strascicabili della Sicilia orientale. Natur. Sicil., S. IV, XVII (3-4): 311-324.

Fredj, G. and C. Maurin. - 1987. Les poissons dans la banque de 
données MEDIFAUNE. Application à l'étude des caractéristiques de la faune ichtyologique méditerranéenne. Cybium, 11(3): 31-139.

Galil, B.S. - 2004. The limit of the sea: the bathyal fauna of the Levantine Sea. Sci. Mar., 68(Suppl. 3): 63-72.

Galil, B.S. and M. Goren. - 1994. The deep sea Levantine fauna - new records and rare occurrences. Senckenberg. Marit., 25: 41-52.

Geistdoerfer, P. - 1975. Ecologie alimentaire des Macrouridae, Téléostéens Gadiformes. Thèse Doctorat ès Sciences. Paris. CNRS AO, 11826: 315 pp.

Geistdoerfer, P. and M. Rannou. - 1972. Poissons benthiques récoltés en Méditerranée occidentale par le N.O. Jean Charcot (campagne Polymède). Bull. Mus. Natn. Hist. Nat., Paris, series 3, 25(19): 101-110.

Giglioli, E.H. - 1881. Italian deep-sea exploration in the Mediterranean. Nature, 24: 381-382

Gilat, E. and A. Gelman. - 1984. On the sharks and fishes observed using underwater photography during a deep-water cruise in the Eastern Mediterranean. Fish. Res., 2: 257-271.

Golani, D. - 1986/87. On deep-water sharks caught off the Mediterranean coast of Israel. Israel J. Zool., 34: 23-31.

Gordon, J.D.M. and J.A.R. Duncan. - 1985. The Ecology of the Deep-sea Benthic and Benthopelagic Fish on the Slopes of the Rockall Trough, Northeastern Atlantic. Prog. Oceanogr., 15: 37-69.

Gordon, J.D.M. - 1979. Lifestyle and phenology in deep sea anacanthine teleosts. Symp. Zool. Soc. London, 44: 327-359.

Goren, M. and B.S. Galil. - 1997. New records of deep-sea fishes from the Levant Basin and a note on the deep-sea fishes of the Mediterranean. Israel J. Zool., 43: 197-203.

Goren, M. and B.S. Galil. - 2002. Records of Cataetyx laticeps and Ophidion barbatum (Ophidiiformes) in the Eastern Mediterranean, with comments on the deep sea ichthyofauna. Cybium, 26(2): 150-152.

Haedrich, R.L. and N.R. Merrett. - 1988. Summary atlas of deepliving demersal fishes in the North Atlantic Basin. J. Nat. Hist., 22: $1325-1362$

Haedrich, R.L. and G.T. Rowe. - 1977. Megafaunal biomass in the deep sea. Nature, 269: 141-142.

Haedrich, R.L., G.T. Rowe and P.T. Polloni. - 1980. The megabenthic fauna in the deep sea south of New England, USA. Mar. Biol., 57: 165-179.

Isaacs, J.D. and R.A. Schwartzlose. - 1975. Active animals of the deep-sea floor. Sci. Am., 233(4): 85-91.

Iwamoto, T. and N. Ungaro. - 2002. A new grenadier (Gadiformes, Macrouridae) from the Mediterranean. Cybium, 26(1): 27-32.

Jones, E.G., A. Tselepides, P.M. Bagley, M.A. Collins and I.G. Priede. - 2003. Bathymetric distribution of some benthic and benthopelagic species attracted to baited cameras and traps in the deep eastern Mediterranean. Mar. Ecol. Prog. Ser., 251: 75-86.

Kallianiotis, A., K. Sophronidis, P. Vidoris and A. Tselepides. 2000. Demersal fish and megafaunal assemblages on the Cretan continental shelf and slope (NE Mediterranean): seasonal variation in species density, biomass and diversity. Prog. Oceanogr. 46: 429-455.

Klausewitz, W. - 1989. Deep-sea and deep water fish of the eastern Mediterranean, collected during the METEOR-Expedition 1987. Senckenberg. Marit., 20(5/6): 251-263.

Labropoulou, M. and C. Papaconstantinou. - 2000. Comparison of otolith growth and somatic growth in two macrourid fishes. Fish. Res., 46: 177-188.

Macpherson, E. - 1979. Ecological overlap between Macrourids in the Western Mediterranean Sea. Mar. Biol., 53: 149-159.

Macpherson, E. and C.M. Duarte. - 1991. Bathymetric trends in demersal fish size: is there a general relationship? Mar. Ecol. Prog. Ser., 71: 103-112.

Marques, A.M. and A.J. Almeida. - 1998. Notes on the biology of Nezumia sclerorhynchus and Nezumia aequalis (Gadiformes: Macrouridae) from the Algarve slope, Northeast Atlantic. Cybium, 22(1): 21-29.

Massutí, E., J.D.M. Gordon, J. Moranta, S.C. Swan, C. Stefanescu and N.R. Merrett. - 2004. Mediterranean and Atlantic deep-sea fish assemblages: differences in biomass composition and sizerelated structure. Sci. Mar., 68(Suppl. 3): 101-115.

Massutí, E., B. Morales-Nin and C. Stefanescu. - 1995. Distribution and biology of five grenadier fish (Pisces: Macrouridae) from the upper and middle slope of the northwestern Mediterranean. Deep-Sea Res., 42(3): 307-330.
Massutí, E., O. Reñones and A. Carbonell. - 1993. A propos de la présence de Trachyscorpia cristulata echinata (Koehler, 1896) en Méditerranée nord-occidentale. Cybium, 17(3): 223-228.

Matarrese, A., G. D'Onghia, A. Tursi and M. Basanisi. - 1996. New information on ichthyiofauna of the South-Eastern Italian coasts (Ionian Sea). Cybium, 20, 197-211.

Maurin, C. - 1962. Etude des fonds chalutables de la Méditerranée occidentale. (Ecologie et Pêche). Rev. Trav. Inst. Pêch. marit., 26(2): $163-218$

Maynou, F. and J.E. Cartes. - 2000. Community structure of bathyal decapod crustaceans off south-west Balearic Islands (western Mediterranean): seasonality and regional patterns in zonation. J. Mar. Biol. Ass. UK, 80: 789-798.

Melley, A., M. Innamorati and G. Mori. - 2000. Cambiamenti termoalini e delle risorse trofiche delle acque intermedie levantine nel Mediterraneo. Biol. Mar. Medit., 7(1): 93-100.

Merrett, N.R. - 1987. A zone of faunal change in assemblages of abyssal demersal fish in the eastern north Atlantic: a response to seasonality in production? Biol. Oceanogr., 5: 137-151.

Merrett, N.R. and R.L. Haedrich. - 1997. Deep-sea demersal fish and fisheries. Chapman and Hall, London.

Morales-Nin, B., E. Massutí and C. Stefanescu. - 1996a. Distribution and biology of Alepocephalus rostratus from the Mediterranean Sea. J. Fish Biol., 48: 1097-1112.

Morales-Nin, B., E. Massutí and C. Stefanescu. - 1996b. Bathymetric distribution and growth patterns of Bathypterois mediterraneus from the north-western Mediterranean Sea. $J$. Fish Biol., 49(suppl. A): 276-288.

Moranta, J., C. Stefanescu, E. Massutí, B. Morales-Nin and D. Lloris. - 1998. Fish community structure and depth-related trends on the continental slope of the Balearic Islands (Algerian basin, western Mediterranean). Mar. Ecol. Prog. Ser., 171: 247-259.

Orsi, L.R. and G. Relini. - 1972. Recenti reperti ittiologici su fondi fangosi batiali del Mar Ligure. Quad. Civ. Staz. Idrobiol. Milano, 3-4: 5-18.

Papaconstantinou, C. - 1988. Fauna Graeciae IV. Check-list of marine fishes of Greece. Hellenic Zoological Society, Athens.

Parenzan, P. - 1960. Pesci abissali e preabissali del Golfo di Taranto. Thalassia Jonica, 3: 3-68.

Pastore, M. - 1976. Note ittiologiche del Golfo di Taranto, $\mathrm{I}^{\circ}$ generalità e lista delle specie. Oebalia, II, 2: 91-103.

Priede, I.G. and P.M. Bagley. - 2000. In situ studies on deep-sea demersal fishes using autonomous unmanned lander platforms. In: R.N. Gibson and M. Barnes (eds.), Oceanogr. Mar. Biol. Ann. Rev., 38: 357-392. Taylor and Francis.

Quignard, J.P. and J.A. Tomasini. - 2000. Mediterranean fish biodiversity. Biol. Mar. Medit., 7(3): 1-66.

Ragonese, S. and G.B. Giusto. - 1999. Su un esemplare di scorfano spinoso, Trachyscorpia cristulata echinata (Pisces Scorpaenidae), catturato nel Mediterraneo occidentale. Biol. Mar. Medit., 6(1): 599-601.

Raimbault, R. - 1963. Notes sur certains espècies ichtyologiques capturées au cours des campagnes de l'Institut des Pêches en Méditerranée (1957-1961). Rév. Trav. Inst. Pêch. Marit., 27(1): 161-171.

Rannou, M. - 1975. Données nouvelles sur l'activité reproductrice cyclique des poissons benthiques bathyaux et abyssaux. C.R. Acad. Sci. Paris, t. 281, Série D: 1023-1025.

Rannou, M. - 1976. Age et croissance d'un poisson bathyal: Nezumia sclerorhynchus (Macrouridae, Gadiforme) de la Mer d'Alboran. Cah. Biol. Mar., 17: 413-421.

Robinson, A. R. and M. Golnaraghi. - 1992. Progress in the understanding of the eastern Mediterranean Sea. Bull. Inst. Océanogr. Monaco, No. special 11: 65-73.

Roule, L. - 1919. Poissons provenant des campagnes du yacht Princesse Alice (1891-1913) et du yacht Hirondelle II (1914). Résultats des Campagnes Scientifiques accomplies par le Prince Albert I, Monaco, 52: 191 pp.

Ryland, J.S. - 2000. European marine biology: past, present and future. Biol. Mar. Medit., 7 (1): 1-27.

Sardà, F., J.E. Cartes, J.B. Company and A. Albiol. - 1998. A Modified Commercial Trawl Used to Sample Deep-Sea Megabenthos. Fish. Sci., 64(3): 492-493.

Sșrensen, T. - 1948. A method of establishing groups of equal amplitude in plant sociology. Vid. Selsk. Biol. Skr., 5: 4 pp.

Stefanescu, C. and J.E. Cartes. - 1992. Benthopelagic habits of adult specimens of Lampanyctus crocodilus (Risso, 1810) (Osteichthyes, Myctophidae) in the western Mediterranean 
deep slope. Sci. Mar., 56: 69-74.

Stefanescu, C., D. Lloris and J. Rucabado. - 1990. Primeras citas de Cataetyx laticeps (Osteichthyes, Bythitidae) y Dysomma brevirostre (Osteichthyes, Synaphobranchidae) en el Mar Catalán (Mediterráneo Ibérico). Misc. Zool., 14: 135-143.

Stefanescu, C., D. Lloris and J. Rucabado. - 1992a. Deep-living demersal fishes in the Catalan Sea (western Mediterranean) below a depth of $1000 \mathrm{~m}$. J. Nat. Hist., 26: 197-213.

Stefanescu, C., D. Lloris and J. Rucabado. - 1993. Deep-sea fish assemblages in the Catalan Sea (westerm Mediterranean) below a depth of 1000 m. Deep-Sea Res., 40 (4): 695-707.

Stefanescu, C., B. Morales-Nin and E. Massutí. - 1994. Fish assemblages on the slope in the Catalan Sea (Western Mediterranean): influence of a submarine canyon. J. Mar. Biol. Ass. UK, 74: 499-512.

Stefanescu, C., J. Rucabado and D. Lloris. - 1992b. Depth-size trends in westerm Mediterranean demersal deep-sea fishes. Mar. Ecol. Prog. Ser., 81: 205-213.

Taning, V.A. - 1918. Mediterranean Scopelidae (Saurus, Aulopus, Chlorophthalmus and Myctophum). Dan. Ocean. Exp., II, A, 7: $154 \mathrm{pp}$.

Theocharis, A., D. Georgopoulos, A. Lascaratos and K. Nittis. 1993. Water masses and circulation in the central region of the
Eastern Mediterranean: Eastern Ionian, South Aegean and Northwest Levantine, 1986-1987. In: Topical studies in Oceanography, Part. II, A.R. Robinson and P. MalanotteRizzoli editors. Deep-Sea Res., 40(6): 1121-1142.

Tortonese, E. - 1960. General Remarks on the Mediterranean DeepSea Fishes. Bull. Inst. Océanogr. Monaco, 1167: 1-13.

Tortonese, E. - 1964. The main biogeographical features and problems of the Mediterranean fish fauna. Copeia, 1: 98-107.

Ungaro, N., G. Marano and G. Rivas. - 2001. Notes on ichthyofauna of the deep basin of the Southern Adriatic Sea. Sarsia, 86: 153-156.

Whitehead, P.J.P., M.-L. Bauchot, J.-C. Hureau, J. Nielsen and E. Tortonese (eds.). - 1984. Fishes of the North-eastern Atlantic and the Mediterranean. 1: 1- 510. UNESCO, Paris.

Whitehead, P.J.P., M.-L. Bauchot, J.-C. Hureau, J. Nielsen and E. Tortonese (eds.). - 1986a. Fishes of the North-eastern Atlantic and the Mediterranean. 2: 517-1007. UNESCO, Paris.

Whitehead, P.J.P., M.-L. Bauchot, J.-C. Hureau, J. Nielsen and E. Tortonese (eds.). - 1986b. Fishes of the North-eastern Atlantic and the Mediterranean. 3: 1015-1473. UNESCO, Paris.

Zugmayer, E. - 1911. Poissons provenant des campagnes du yacht Princesse Alice. Résultats des Campagnes Scientifiques accomplies par le Prince Albert I, Monaco, 35: 1-174. 
